\title{
Turist Rehberliği Meslek Kanununun Profesyonel Turist Rehberlerince Değerlendirilmesi
}

\section{The Evaluation of Tourist Guiding Law by the Perspective of Professional Tourist Guides}

Doç. Dr. Burhanettin ZENGIN

Sakarya Üniversitesi

Turizm Fakültesi

E-posta: bzengin@sakarya.edu.tr

Orcid Id:0000-0002-6368-0969
Arş. Gör. Nuray EKER

Sakarya Üniversitesi

Turizm Fakültesi

E-posta: nurayeker@sakarya.edu.tr

Orcid Id:0000-0002-2891-2592

\section{Yrd. Doç. Dr. Gül ERKOL BAYRAM}

Sinop Üniversitesi

Turizm İşletmeciliği ve Otelcilik Yüksekokulu

E-posta: gulerkol@sinop.edu.tr

Orcid Id:0000-0001-9764-2883

\section{Öz}

Türkiye'de profesyonel turist rehberliği mesleği 22 Haziran 2012 tarih ve 6326 sayılı "Turist Rehberliği Meslek Kanunu" ile yasal bir statüye kavuşmuştur. Ancak bu kanunun profesyonel turist rehberlerinin sorunlarının giderilmesinde yeterli olup olmadığı ve bu yasanın bizzat mesleği icra eden kişilerce nasıl değerlendirildiği henüz bir muammadır. Buradan hareketle çalışmanın temel amacı Turist Rehberliği Meslek Kanunu ve bu yasaya istinaden çıkarılan yönetmeliğin rehberler bakış açısıyla değerlendirilmesinin ortaya konmasıdır. Yapılan ön çalışmaların ardından bir tutum ölçeği oluşturulmuştur. İstanbul ilinde aktif olarak çalışan rehberlere uygulanarak elde edilen 393 anketten 345 tanesi analize uygun bulunmuştur. Araştırmada elde edilen veriler doğrultusunda meslek kanununun rehberlik mesleğini yasal bir statüye kavuşturduğu, ancak rehberlerin sorunlarını gidermede yetersiz kaldığı söylenebilir.

Anahtar Kelimeler: Profesyonel turist rehberleri, Rehberlik meslek kanunu, Değerlendirme

\begin{abstract}
Professional Tourist Guiding in Turkey has gained to legal status in June 22th 2012 and with "Tourist Guiding Professional Law Act. No. 6326". But it is not yet clear how guides evaluate the law, whether it is enough for solution of the problems or not. The purpose of this study is to reveal how tourist guides evaluate the Tour Guide Law and regulations about this law. An attitude scale was created after the preliminary studies. The scale has been delivered to tour guides in Istanbul, then 345 were eligible for analysis $t$ of the 393 return survey. According to the result of research, it was found that with Tourist Guiding Law vocational guiding has gained the status but because of the lack of control it couldn't solve some problems.
\end{abstract}

Keywords: Professional tourist guides, Tourist guiding professional law act, Evaluation of tour guide 


\section{Giriş}

Turist rehberleri ziyaretçilerine eşlik eden, onlara ülkenin değerlerini tanıtan ve sevdiren, yerel halk ile ziyaretçiler arasında etkileşim sağlayan, ülkesinin somut ve soyut miraslarını koruyan, ülkesinin tanıtımında imaj geliştirici bir vazife üstlenen bireyler olarak turizm sektöründe önemli bir yere sahiptir (Yenipınar vd., 2014: 87). Çoğu zaman ülkesinin kültür elçisi olarak nitelendirilen (Ap ve Wong, 2001: 552; Dahles, 2002: 785; Batman, 2003: 118; Lecrec ve Martin, 2004: 181; Avcıkurt vd.,2009: 59; Ong vd., 2014: 227) profesyonel turist rehberlerinin mesleklerini büyük bir özveri ile icra etmeleri gerekmektedir (Yarcan, 2007: 35; Köroğlu, 2013: 92). Zira onların başarı ve başarısızlığı turun başarısıyla doğrudan ilişkilidir.

Bir ülkede turizmin gelişmesinde ve ülkenin olumlu bir imaj sergilemesinde büyük öneme sahip profesyonel turist rehberlerine haklar tanınması, onların misafirlerine sunacağı hizmet kalitesini etkileyecektir (Liu ve Yee; 2012: 96). Diğer taraftan profesyonel turist rehberleri meslek hayatlarında çeşitli sorunlarla karşlaşmakta, bu sorunlar onların performanslarını etkileyebilmektedir. Gerek bu sorunları giderebilmek, gerekse de rehberlik mesleğini yasal bir zemine oturtmak adına 22 Haziran 2012 tarihinde 6326 sayılı Turist Rehberliği Meslek Kanunu yasalaşarak yürürlüğe girmiştir.

Yıllardır beklenen ve üzerinde çalışmalar sürdürülen kanunun çıkarılması meslek mensuplarını memnun etmiş; ancak uygulamada sorunları çözüp çözemeyeceği konusunda kafalarda bazı soru işareti bırakmıştır. Ayrıca yeni kanunla birlikte rehber odalarına kayıt gibi bazı yasal zorunlulukların rehberlerce ne derece olumlu karşılandığı bilinmemektedir. Bu çalışmada Turist Rehberliği Meslek Kanunun Profesyonel Turist Rehberlerince yeterliliğinin değerlendirilmesi amaçlanmıştır. Bu çalışma; meslek mensuplarına ve ilgili kurum ve kuruluşlara yol gösterici niteliği taşıması, turist rehberlerinin haklarının korunması, mevzuattaki eksik yönlerin belirlenmesi ve gelecekte mevzuat üzerinde yapılacak düzenlemelere ışık tutabilmesi adına önem arz etmektedir. Öte yandan bu konuda yapılan ilk nicel çalışma özelliği ile de özgünlüğünü korumaktadır. Araştırma sonucuna istinaden, kanunda eksik kalan yönlerin rehberlerin lehine olacak şekilde yeniden düzenlenebileceği düşünülmektedir.

\section{Rehberlik Mesleğinin Tanımı, Önemi ve Yasal Süreci}

Organize turların başlangıcından bitimine kadar misafirlerine eşlik eden profesyonel turist rehberleri sadece tercümanlık yapan kişiler değil; ziyaretçilerin farklı kültürleri tanımasını, seyahat deneyimi kazanmasını sağlayan, bir destinasyondaki doğal, tarihi ve kültürel varlıklar hakkında bilgileri eğlendirici bir üslupla ziyaretçilerine aktaran kişilerdir (Ap ve Wong , 2001: 551; Dahles, 2002: 787). Ahipaşaoğlu, (2001: 91) profesyonel turist rehberi tanımlamasında onun çok yönlülüğüne vurgu yaparak gerektiğinde yaylacılık, dağ ve doğa yürüyüşleri, su sporları, avcılık, kayak, mağaracılık, ornitoloji, paraşütçülük, botanik, bisiklet ve at turlarını kapsayan çeşitli spor türlerinin uygulanmasına yardımcı olabileceğini ifade etmektedir. Turist rehberlerinin çok yönlülüğüne vurgu yapan Zhang ve Chow (2004: 82), turist rehberlerinin aktör, arabulucu, kültür elçisi, yorumcu, öğretmen, çevirmen, denge unsuru, satış elemanı gibi roller üstlendiğini belirtmektedir.

Gerek ülke turizminin, gerekse turizm işletmelerinin aynası konumunda olan turist rehberlerinin (Batman vd., 2000: 27), misafirler ile yerel halk arasında etkileşimi sağladıkları ve bir köprü görevi üstlendikleri düşünüldüğünde önemi yadsınamaz (Güzel, 2007: 8; Yenipınar vd., 2014: 87). Öte yandan yabancı kültürleri tanıdık hale 
getirmesi, farklı kültürlerin tanınması, kültürler arası bilgilerin aktarılması ve devamlılığının sağlanması adına turist rehberlerinin büyük önem taşıdığı düşünülmektedir (Cohen, 1985: 1).

Seyahatleri süresince turistlerle en çok vakit geçiren, deneyimlerini ve bilgilerini aktaran, onlara yol gösteren bireyler olarak turist rehberlerinin sergiledikleri performanslar, turun başarısını, müşteri memnuniyetini ve uzun vadede müşteri sadakatini doğrudan etkilemektedir (Çimrin, 1995: 9; Wang vd., 2000: 178; Bowie ve Chang, 2005: 305). Profesyonel turist rehberlerinin sergiledikleri başarı sadece turist memnuniyetine değil, ülke imajına da etki etmektedir. Bir destinasyonun tanıtılmasında, iyi ya da kötü olarak nitelendirilmesinde, turistik yönelimin olumlu bir imaj çizebilmesinde ve var ise olumsuz bir imajın yok edilmesinde stratejik bir konumda olduğu söylenebilir (Tosun ve Temizkan, 2004: 353; Temizkan vd., 2013: 477). Dolayısıyla turist rehberlerinin sundukları tüm hizmetler misafirlerin zihnindeki olumsuz imaj ve önyargılarının değişmesine, yanlışların düzeltilmesine ve eksik bilgilerin tamamlanmasına katkılar sunmaktadır.

Geçmişi yüzlerce yıl önceye dayanan rehberliğin modern anlamda ülkemizde ortaya çıkışı 19. yüzyıla rastlamaktadır. Tanzimat Fermanının (1839) ardından İstanbul'a ticaret amaçlı gelen iş adamlarına tercümanlık yapmak üzere Ermeni, Rus, Süryani, Musevi, Fransız, İtalyan ve Maltalı Levanten ailelerin çocukları tercüman rehberlik yapmış; dine aykırı olduğu gerekçesi ile Müslüman tebaa uzun süre meslek dışında kalmıştır (Ahipaşaoğlu, 2001: 6; Batman vd., 2001: 190). Bu dönemde tercüman rehberlerin devlet aleyhine söylemleri üzerine Osmanlı yönetimi 20 Ekim 1890 yılında Seyyahine Tercümanlık Edenler Hakkında 190 Sayılı Nizamnameyi yayınlamıştır.

Türkiye Cumhuriyeti'nin kurulmasından sonra rehberlik mesleğini disiplin altına almak adına 1925 ve 2730 sayılı tarihli Ecnebi Seyyahlara Tercümanlık ve Rehberlik Edecekler Hakkında Kararname yayınlanmış ve turist rehberliğine yönelik çeşitli adımlar atılmıştır (TBMM, 2012). 1928 yılında yaşanan ekonomik kriz ile turizm faaliyetleri olumsuz yönde etkilendiğinde birçok rehber mesleği terk etme noktasına gelmiştir, fakat Aralık ayında İstanbul İktisat Müdürlüğü tarafından bir rehberlik kursunun açılacağı beyan edilmiştir. Böylelikle ilk kez bir sınavdan geçerek kazanılan hak ile kurstan mezun olan rehber sayısı 50'ye ulaşmıştır (Yenipınar, Bak ve Çapar, 2014: 91).

1971 yılında "Tercüman Rehber Kursları ve Tercüman Rehber Yönetmeliği" adıyla turist rehberliği ile ilgili ilk yönetmelik yayımlanmıştır. Bu yönetmelik 1974 tarihinde değiştirilerek "Profesyonel Turist Rehberliği Yönetmeliği" adını almış, 1981, 1983 ve 1986 yıllarında değişikliklere uğramıştır (TBMM, 2012). O yıllardan itibaren rehberlik mesleğinin bir meslek olarak tanınması, yasal hakların kazanılması ve ilgili kanunun çıkarılması için sektörde çalışan rehberler, meslek odaları, akademisyenler ve daha pek çok ilgili kişi ve kurum tarafından çaba sarf edilmiştir. En nihayetinde yaklaşık 30 yıllık bir bekleyişin ardından 2012 yılında meslek yasallaştııılmıştır.

En son halini 2005 yılında alan "Profesyonel Turist Rehberliği Yönetmeliği" ile 6326 sayılı Turist Rehberleri Meslek Kanunu ardından çıkarılan, 23 Şubat 2013 tarihli resmi gazetede yayınlanan Turist Rehberliği Meslek Yönetmeliği arasında bazı değişiklikler bulunmaktadır. Yönetmelikte yapılan değişikliklerden biri (madde 3) aktif ve pasif rehberlik kavramı yerine "eylemli" ve "eylemsiz" kavramlarının kullanılmasıdır. 
Eylemli turist rehberi: Çalışma kartı sahibi olup fiilen turist rehberliği hizmeti sunma hak ve yetkisine sahip turist rehberini,

Eylemsiz turist rehberi: Ruhsatname sahibi olup çalışma kartı olmayan turist rehberini ifade etmektedir.

Çalışma kartı: Eylemli turist rehberlerine, kayıtlı oldukları oda tarafından bir yıl süreyle geçerli olmak üzere mesleği fiilen icra edebileceklerine ilişkin verilen ve rehberlik hizmeti verilmesi esnasında görünür bir şekilde taşınan izin belgesini,

Ruhsatname: Mesleğe kabul koşullarını taşıyan turist rehberlerine Bakanlık tarafından verilen belgeyi ifade etmektedir.

Eski yönetmelik üzerinde yapılan değişikliklerden birisi de, eskiden "vize" olarak ifade edilen ve bakanlıkça düzenlenen seminerlere katılımın ardından bağlı bulunan ildeki Kültür ve Turizm İl Müdürlüğünce verilen bir yıllık çalışma izninin meslek odalarına devredilmiş olmasıdır. Zira söz konusu yönetmeliğin 31 . maddesi turist rehberlerinin, yerleşim yerinin bulunduğu ilde kurulmuş bölgesel odalardan birine, yerleşim yeri olan ilde oda kurulmamışsa en yakın ilde kurulmuş odalardan birine üye olmaları zorunluluğundan bahsetmektedir. Ayrıca 6326 sayılı kanunla birlikte kursların bakanlık tarafından yapılması şartı kaldırılmış, yerine odalar tarafından yapılması getirilmiştir. Yapılan bir diğer değişiklik yabancı dil şartının en az C seviyesinden en az B seviyesine yükseltilmiş olmasıdır (Madde 3/r). Yönetmelikteki bir diğer köklü değişiklik ise zorunlu uygulama gezisinin 36 günden 45 güne çıkarılmasıdır. Aynı yönetmeliğin 34 ve 35 . maddelerinde ise taban ücret ve taban ücrete uyma zorunluluğundan bahsedilmektedir.

Yönetmelikte yapılan bir diğer önemli değiş̧iklik ise eğitim ile ilgilidir. 2005 yılı yönetmeliğinde kursa katılmak için asgari eğitim şartı ön lisans düzeyinde iken bu şart lisans düzeyine çıkarılmış ve ders saatleri ülkesel düzeyde rehberlik için 560 saatten 700 saate çıkarılmıştır. Meslek kanunu ve turist rehberliği eğitimini çalışmalarında değerlendiren Temizkan ve arkadaşları ders saatlerini arttırmak gibi iyileştirmelerin, üniversite düzeyinde eğitim ile sertifika programındaki eğitim arasındaki adaletsizliği ortadan kaldırmayacağını ve yakınmaların devam edeceğini ifade etmişlerdir.

\section{Literatür Taraması}

Turist rehberlerinin sorunlarına ilişkin literatürde pek çok çalışma yapılmış olup mesleğin yasal statüye kavuşmasına sıklıkla vurgu yapılmıştır (Batman, 2003; Tetik, 2006; Akbulut, 2006; Yarcan, 2007; Yazıcıoğlu vd., 2008; Çetin ve Kızılırmak, 2012).. Rehberlik mesleği bir taraftan zevkli, rahat ve bol kazanç getiren bir meslek olarak düşünülürken, diğer taraftan pek çok güçlükle karşılaşılan bir meslektir ve bu problemlerin yaşanmasında meslek yasasının olmayışı ve rehberlerin iş ve sağlık güvenliğinin olmayışının etkisi büyüktür (Tetik, 2006: 11). Batman (2003) yaptığı çalışmada profesyonel turist rehberlerinin karşılaştıkları kaçak rehberlik, taban ücretin altında çalışma, kimlik sorunu, sosyal hakların eksikliği işletmelerle yaşanan sorunlar ve turist gruplarıyla yaşanan sorunlara değinerek rehberlere daha iyi olanaklar sunan bir düzenlemenin gerekliliğine vurgu yapmıştır. Yarcan (2007) ise çalışmasında meslek yasasının çıkması ve etik konusunun yasada ele alınması ile bu sorunların çözüme kavuşabileceğine değinmiş ve yasanın gücünün rehberlerin ilkelere ilişkin duyarlılığını arttıracağını ifade etmiştir. Akbulut (2006), Ege bölgesindeki turist rehberlerin meslek sorunlarına ilişkin hazırladığı yüksek lisans tezinde rehberlerin yaşadıkları sorunların ifadesinde yasal düzenlemelerin yetersiz kaldığı sonucuna ulaşmış; başarılı bir rehberlik hizmeti için, mesleki yasallaşmanın gerekliliğine değinmiştir. Çetin ve Kızılırmak (2012) yasanın işlerlik kazandırılmadığı sürece kaçak rehberlik ve taban ücretin altında rehber çalıştırılmasının önüne geçilmesinde zorluk yaşanacağı ve bu durumun rehber kalitesinin düşereceğini belirtmiştir. Köroğlu ve Avcıkurt (2014), 
rehberlerin motivasyon ve performanslarını arttırmak için uygun strateji ve araçların uygulamaya konmasının önem taşıdığını; rehberlerin meslek olarak tanınmasının rehberlerin sorunlarının önüne geçebileceğini ifade etmişlerdir.

22 Haziran 2012 tarih ve 6326 sayılı "Turist Rehberliği Meslek Kanunu" nun Resmi Gazete'de yayımlanmasının ardından bu konuya ilişkin çalışmalar mevcuttur (Temizkan vd. 2013; Güzel vd., 2014; Yenipınar vd., 2014). Temizkan ve arkadaşları (2013) Turist Rehberliği Meslek Kanunu ve rehberlik eğitimini değerlendirmek üzere yaptıkları ve eğitimin önemini vurguladıkları çalışma sonucunda yasanın eğitim ve mesleğe kabul sorununu çözemediğini ifade etmişlerdir. Türkiye'de farklı nitelikte ve sürelerde verilen rehberlik eğitiminin standartlaşmadan uzak olduğu ve fırsat eşitliğine engel taşıdığı belirtilen bu çalışmada Temizkan ve arkadaşları yeni yasada da sertifika programlarının etkin olduğuna ve üniversitelerin rehberlik eğitimi konusunda yedekte tutulduğuna değinmişlerdir. Bunun temel sebebinin üniversitelerin sadece İngilizce dilinde rehber yetiştirmesi ve rehberlik eğitiminin meslek odaları için önemli bir gelir kaynağı olamaması araştırma sonucunda açıkça ifade edilmiştir.

Turist Rehberliği Meslek Kanunu'nun değerlendirilmesi üzerine yapılan bir diğer çalışma Yenipınar ve arkadaşlarına aittir (2014). Yenipınar ve arkadaşları yaptıkları bu çalışmada Turist Rehberliği Meslek Kanunu'nun olumlu yönleri, olumsuz yönleri ve yapılan eleştirilere yer vermiştir. Buna göre

Turist Rehberliği Meslek Kanunu'nun Olumlu Yönleri:

- Mesleğin yasal statüye kavuşması,

- Mesleğin itibarının artması,

- Rehber haklarının güvence altına alınması,

- Birlik beraberliğin korunması

- Meslek örgütlerinin söz sahibi olması

- Kaçak rehberliğin önüne geçilmeye çalışılması

- Acentelere taban ücret ödeme zorunluluğunun getirilmesi

- Rehberlere yönelik zorunlu seminerlerin kaldırıması

- Meslek odalarının kurulması

- Denetimlerin artması

Turist Rehberliği Meslek Kanunu'nun Olumsuz Yönleri:

- Yetkilerin Bakanlık 'ta toplanması

- Sertifika programlarının yetersizliği

- Gezi ücretlerinin yüksek olması

- Meslek odalarının gelirleri

- Birlik ve oda arasında koordinasyon sorunu yaşanması intimali

- Eğitimdeki üçlü yapının devam ediyor olması

- SGK ve vergi konusu

- Türkçe rehber olunamaması

- Bakanlık ve TUREB sınavlarının yetersizliği

- Yetersiz denetimler

Turist Rehberliği Meslek Kanununa Yönelik Eleştiriler

- Kanunun yetersizliği

- Akademisyenlerin ve meslek kuruluşlarının kanun düzenlemesinde söz sahibi olamamaları

- Turist rehberliği eğitimindeki adaletsizlik

- Taban yevmiye sorunu

- Rehberlerin kazanılmış hakkının alınması

- Kaçak rehberliğin tam anlamıyla önüne geçilememiş olması

- Mesleğin kalitesizleşmesi 
Güzel ve arkadaşları da yaptıkları çalışmada (2014) meslek yasasına ilişkin bir takım verilere ulaşmıştır. Bu çalışmada elde edilen bulgulara göre katılımcılar yasanın rehberlik haklarını yeterince korumadığını ve rehberlerin yasaya aykırı davranması konusunda baskı gördüğünü düşünmektedir. Öte yandan her ne kadar rehberlik meslek yasası ile denetimler yaygınlaşmış olsa da kaçak rehberliğin halen mesleğin önündeki en önemli engel olarak görüldüğü anlaşılmıştır. Ayrıca yasaya istinaden çıkarılan yönetmelikte taban ücretlerin altında rehberlik yapanlar ve yaptıranlar hakkındaki yaptırımlar açıkça ifade edilmiş olsa da, meslek yasasının bu konuda da yeterli olamadığı sonucuna ulaşılmıştır.

Yapılan bu çalışmalar incelendiğinde rehberlik mesleğinin meslek kanunu ile yasal bir statüye kavuştuğu ancak kaçak rehberlik, taban ücretlerin altında rehber çalıştırılması ve denetimlerdeki yetersizlik gibi turist rehberlerinin en sık karşılaştıkları konularda yetersiz kaldığı anlaşılmaktadır. Her ne kadar rehberlik mesleği yasal bir statüye kavuşmuş olsa da acentaların ruhsatname sahibi olmayan kişileri rehber olarak çalıştırmaları ve bu kişilerin bir rehber gibi davranmaları, rehberlik mesleğini icra etmeye hak kazanan kişileri zor durumda bırakmaktadır. Çalışmanın bundan sonraki kısmında Turist Rehberleri Meslek Kanunu'na ilişkin rehberlerin değerlendirmeleri yer almaktadır.

\section{Araştırmanın Yöntemi}

Nicel bir araştırma tekniği kullanılan bu araştırmada turist rehberlerine yönelik uygulanan anketler ile veriler elde edilmiştir. Türkiye'de turizm sektöründe 2014-2015 yılı itibariyle eylemli olarak çalışan 7879 ve eylemsiz olarak bulunan 2092 rehber olmak üzere toplam T.C. Kültür ve Turizm Bakanlığı'ndan belgeli 9971 turist rehberi bulunmaktadır (TUREB, 2015). Araştırmanın genel evreni öncelikle turizm sektöründe eylemli olarak çalışan 7879 rehberden oluşmaktadır ${ }^{1}$.

$\mathrm{Bu}$ araştırma kapsamında kullanılan anketler Ayasofya, Topkapı Sarayı, Sultan Ahmet Camii gibi turistlerin sıklıkla ziyaret ettikleri yerlerde turistlere eşlik eden çalışma kartına sahip rehberlere uygulanmıştır. Araştırma süreci sonunda toplam 393 anket toplanmıştır. Bu anketlerin belirli bir kısmı yeterli veri ve anlamlılığa sahip olmadığı için değerlendirmeye alınmamıştır. 345 anket formu üzerinden araştırma analizleri gerçekleştirilmiştir. Örneklemin tespit edilmesinde kasti örnekleme yöntemi kullanılmıştır.

Araştırma kapsamında ilgili literatür taranmış ve meslek yasası çıkmadan önce rehberlerin karşılaştıkları sorunlar irdelenmiştir. Profesyonel turist rehberlerinin karşılaştıkları sorunlara ilişkin deneyimli rehberlerin ve oda başkanlarının görüşleri alınmıştır. Nicel bir yöntemin kullanıldığı bu araştırmada kullanılan tutum ölçeği, literatür taraması ve görüşmelerin ardından araştırmacılarca oluşturulmuştur. Araştırmada kullanılan ölçek pilot bir çalışma ile ele alınmış ve 3. Uluslararası Turizm Araştırmaları Kongresi'nde (ICTMR'16) yazılı ve sözlü olarak sunulmuştur. Araştırmada kullanılacak anket formu iki bölümden oluşmaktadır. İlk bölüm demografik özellikleri ve mesleki durumlarını tespit etmeye yönelik 11 ifadeden oluşmaktadır. İkinci bölümde meslek yasası kavramına yönelik bilgileri içeren 30 adet soru sorulmuştur. Anket formunun ikinci bölümüne ait sorular 5'li Likert tipi soru formuna göre hazırlanmıştır. Bu duruma göre oluşturulan anket formunda yer alan ifadeler en olumsuzdan en olumluya doğru (1: Kesinlikle katılmıyorum, 2: Katılmıyorum, 3: Kısmen

\footnotetext{
${ }^{1}$ Eylemsiz rehberler T.C. Kültür ve Turizm Bakanlığı'ndan ruhsatnameli olmalarına rağmen herhangi bir nedenle çalışma kartı almayan ve çalışmayan rehberleri ifade etmektedir. Bu nedenle eylemsiz rehberler araştırmada örneklem dışında tutulmuştur.
} 
Katılıyorum, 4: Katılıyorum, 5: Kesinlikle katılıyorum) derecelendirilmiştir. 228 katılımcı ile gerçekleşen ve İstanbul İli ile sınırlanan ön test sonucunda ölçek, pilot çalışmaya getirilen eleştiriler ve öneriler doğrultusunda düzenlenerek araştırma evreni genişletilmiş ve Türkiye'deki profesyonel turist rehberlerini kapsamıştır. Bu araştırmada olasılığa dayalı olmayan örnekleme yöntemlerinden kasti örnekleme metodu kullanılmıştır. Alan araştırması neticesinde geri dönüşü sağlanan 393 anketten yanlış, eksik ve hatalı cevaplananları elenerek $345^{\prime}$ inin sonuçları analiz edilmiştir. Anketlerin sonuçları için frekans, faktör analizi, T-Testi ve One-way Anova, analizi kullanılmıştır

\subsection{Araştırmanın Hipotezleri}

Çalışma kapsamında, profesyonel turist rehberlerinin meslek yasasına yönelik tutumlarının ile demografik değişkenler ile mesleki verilerine yönelik farkıı̆ı̆ın boyutu tespit edilmeye çalışılmıştır. Bu durum aşağıda verilen hipotezler neticesinde şekillenmiştir;

H1. Rehberlerin demografik özellikleri ile meslek yasasına yönelik tutumları arasında istatistiksel açıdan anlamlı bir farklılık vardır.

$\mathrm{H} 2$ : Rehberlerin cinsiyetleri ile meslek yasasına yönelik görüşleri arasında istatistiksel açıdan anlamlı bir farklılık vardır.

H2: Rehberlerin eğitimleri ile meslek yasasına yönelik görüşleri arasında istatistiksel açıdan anlamlı bir farklılık vardır.

H3: Rehberlerin gelir durumu ile meslek yasasına yönelik görüşleri arasında istatistiksel açıdan anlamlı bir farklılık vardır.

H4: Rehberlerin rehberlik statüsü ile meslek yasasına yönelik görüşleri arasında istatistiksel açıdan anlamlı bir farklılık vardır.

H5: Rehberlerin mesleki tecrübeleri ile meslek yasasına yönelik görüşleri arasında istatistiksel açıdan anlamlı bir farklılık vardır.

H6: Rehberlerin ruhsatname alma yerleri ile meslek yasasına yönelik görüşleri arasında istatistiksel açıdan anlamlı bir farklılık vardır.

$\mathrm{H} 7$ : Rehberlerin ekli yabancı dil sayıları ile meslek yasasına yönelik görüşleri arasında istatistiksel açıdan anlamlı bir farklılık vardır.

\section{Araştırmanın Bulguları}

Tablo 1: Demografik Veriler

\begin{tabular}{|c|l|c|c|}
\hline & & $\mathbf{n}$ & $\%$ \\
\hline \multirow{4}{*}{ Cinsiyet } & Kadın & 106 & 30,7 \\
\cline { 2 - 4 } & Erkek & 236 & 68,4 \\
\cline { 2 - 4 } & Belirtilmemiş & 3 & 9 \\
\cline { 2 - 4 } & Toplam & 345 & 100,0 \\
\hline \multirow{5}{*}{ Yaş } & $18-25$ & 39 & 11,3 \\
\cline { 2 - 4 } & $26-35$ & 134 & 38,8 \\
\cline { 2 - 4 } & $36-45$ & 106 & 30,7 \\
\cline { 2 - 4 } & $46-55$ & 54 & 15,7 \\
\cline { 2 - 4 } & 56 ve üzeri & 12 & 3,5 \\
\cline { 2 - 4 } & Toplam & 345 & 100,0 \\
\hline \multirow{5}{*}{ Eğitim } & Lise & 21 & 6,1 \\
\cline { 2 - 4 } & Ön Lisans & 85 & 24,6 \\
\cline { 2 - 4 } & Lisans & 211 & 61,2 \\
\cline { 2 - 4 } & Lisansüstü & 28 & 8,1 \\
\cline { 2 - 4 } & Toplam & 345 & 100,0 \\
\hline
\end{tabular}


Tablo 1'in Devamı

\begin{tabular}{|c|l|c|c|}
\hline \multirow{5}{*}{ Gelir } & Belirtilmemiş & 2 &, 6 \\
\cline { 2 - 4 } & $1000 \mathrm{TL}$ 'den az & 35 & 10,1 \\
\cline { 2 - 4 } & $1001-2000 \mathrm{TL}$ & 63 & 18,3 \\
\cline { 2 - 4 } & $2001-3000 \mathrm{TL}$ & 97 & 28,1 \\
\cline { 2 - 4 } & $3001-4000 \mathrm{TL}$ & 72 & 20,9 \\
\cline { 2 - 4 } & 4001-5000 TL & 44 & 12,8 \\
\cline { 2 - 4 } & 5001-6000 TL & 21 & 6,1 \\
\cline { 2 - 4 } & 6000 TL'den fazla & 11 & 3,2 \\
\cline { 2 - 4 } & Toplam & 345 & 100,0 \\
\hline
\end{tabular}

Tablo 1'de ankete katılan rehberlerin demografik özellikleri verilmektedir. Tabloya göre \%68,4'ü erkeklerden oluştuğu katılımcıların \% 38,8'inin 26-35 yaş aralığında olduğu tespit edilmiştir. Katılımcıların eğitim durumları incelendiğinde ise $\% 85,8$ oranında lisans ve ön lisans mezunu olduğu görülmektedir. Gelir durumlarına bakıldığında; \% 28,1'inin 2001-3000 TL, \% 20,1'inin 3001-4000 TL, \% 18,3'ünün 10012000 TL, \% 12'8'inin 4001-6000 TL , \%10,1'inin 1000 TL'den az, \%6,1'inin ise 50016000 TL, \% 3,2'sinin ise 6000 TL'den fazla kazandığı görülmektedir.

Tablo 2: Mesleki Veriler

\begin{tabular}{|c|c|c|c|}
\hline \multirow{6}{*}{ Çalışma Şekli } & Belirtilmemiş & 5 & 1,4 \\
\hline & Bağımsız & 152 & 44,1 \\
\hline & Bir Acentada Kadrolu & 117 & 33,9 \\
\hline & Bir Seyahat Acentası İle Anlaşmalı & 54 & 15,7 \\
\hline & Diğer & 17 & 4,9 \\
\hline & Toplam & 345 & 100,0 \\
\hline \multirow{5}{*}{ Ekli Dil Sayısı } & Tek Dil & 203 & 58,8 \\
\hline & $2 \mathrm{Dil}$ & 114 & 33,0 \\
\hline & $3 \mathrm{Dil}$ & 26 & 7,5 \\
\hline & $5 \mathrm{Dil}$ & 2 & 6 \\
\hline & Toplam & 345 & 100,0 \\
\hline \multirow{6}{*}{$\begin{array}{l}\text { Mesleki } \\
\text { Tecrübe }\end{array}$} & 1 Yıldan az & 29 & 8,4 \\
\hline & $1-3 Y_{I I}$ & 80 & 23,2 \\
\hline & 4-6 YII & 105 & 30,4 \\
\hline & $7-10 Y_{I I}$ & 65 & 18,8 \\
\hline & 10 Yıldan fazla & 66 & 19,1 \\
\hline & Toplam & 345 & 100,0 \\
\hline \multirow{4}{*}{ Çalışma Alanı } & Ülkesel & 211 & 61,2 \\
\hline & Uluslararası & 99 & 28,7 \\
\hline & Bölgesel & 35 & 10,1 \\
\hline & Toplam & 345 & 100,0 \\
\hline \multirow{6}{*}{$\begin{array}{c}\text { Ruhsatname } \\
\text { Alma Şekli }\end{array}$} & Belirtilmemiş & 5 & 1,4 \\
\hline & Meslek Kursları & 91 & 26,4 \\
\hline & Ön Lisans Diploması & 80 & 23,2 \\
\hline & Lisans Diploması & 162 & 47,0 \\
\hline & Diğer & 7 & 2,0 \\
\hline & Toplam & 345 & 100,0 \\
\hline
\end{tabular}

Tablo 2'de rehberlere ait mesleki veriler yer almaktadır. Tabloya göre araştırmaya katılan rehberlerin yarıya yakını (\%44,1) bağımsız olarak çalışmaktadır. Analizler incelendiğinde; \% 58,8'i tek dil bilen ve \%47'si lisans diploması ile ruhsatnamelerini alan katılımcıların yarıdan fazlası $(\% 61,2)$ ülkesel olarak çalışmaktadır. Mesleki tecrübeye bakıldığında ise en yüksek deneyimin \% 30,4 katılımcı oranı ile 4-6 arasında olduğu görülmektedir. 
Tablo 3: Meslek Yasasına Yönelik İfadelerin Ortalama ve Standart Sapmaları

\begin{tabular}{|c|c|c|}
\hline İfadeler & $\bar{X}$ & SS \\
\hline 1. Meslek yasası ile meslek yasal bir statüye kavuşmuştur & 2,15 & 1,062 \\
\hline 2. Meslek yasası ile denetimler artmıştır & 2,60 & 1,188 \\
\hline $\begin{array}{l}\text { 3. Meslek yasası çıktıktan sonra seyahat işletmeleri ile olan ilişkilerimiz } \\
\text { iyileşmiştir }\end{array}$ & 2,48 & ,967 \\
\hline 4. Meslek yasası rehberlere devamlı iş garantisi sağlar & 3,07 & 1,023 \\
\hline 5. Yasa dili yetişkin bir bireyin anlayabileceği açıklıktadır & 2,69 & 1,150 \\
\hline 6. Meslek odaları daha iyi iletişim kurmamızı sağlar & 2,29 & 1,002 \\
\hline 7. Meslek yasası meslek haklarımızı korumaktadır & 2,32 & 1,016 \\
\hline 8. Meslek yasası rehberlerin daha iyi bir statü edinmesini sağlar & 2,28 & 1,096 \\
\hline 9. Yasa uygulaması taban ücretin üzerinde bir ücret almamı sağlamıştır & 2,88 & 1,081 \\
\hline 10. Eylemli-eylemsiz rehber uygulamasını doğru buluyorum & 2,42 & 1,149 \\
\hline 11. Meslek yasası kaçak rehberliğin önlenmesini sağlar niteliktedir & 2,80 & 1,254 \\
\hline 12. Meslek yasası sosyal haklarımızı güvence altına alır & 2,44 & 1,114 \\
\hline 13. Meslek Odalarına kayıt zorunluluğu rehberlere avantaj sağlar & 2,31 & 1,009 \\
\hline 14. Meslek yasası seyahat acentaları ile ücret anlaşmazlıklarını ortadan kaldııı & 2,82 & 1,060 \\
\hline 15. Meslek yasası ile rehberlik mesleği daha sağlam bir zemine oturmuştur & 2,41 & 1,005 \\
\hline $\begin{array}{l}\text { 16. Yasa rehberler ile seyahat acentaları arasında sosyal haklar konusundaki } \\
\text { sorunları çözer }\end{array}$ & 2,73 & ,978 \\
\hline $\begin{array}{l}\text { 17. Yeni yasada yabancı dil puan barajının B seviyesine çıkarılması yerinde bir } \\
\text { uygulamadır }\end{array}$ & 2,33 & 1,076 \\
\hline 18. Meslek yasası mesleğimi daha fazla benimsememi sağlamıştır & 2,28 & 1,097 \\
\hline 19. Meslek yasası sektördeki fiyat kırma politikalarını önler & 2,83 & 1,136 \\
\hline 20. Meslek yasası çıktıktan sonra çalışma şartlarımız iyileşmiştir & 2,58 & ,976 \\
\hline 21. Meslek yasası işletmelerle olan ilişkilerimizin iyileşmesini sağlar & 2,56 & ,989 \\
\hline 22. Meslek odaları sorunlarımızın çözüm bulmasına yardımcı olur & 2,46 & ,942 \\
\hline 23. Meslek yasası rehberlik mesleğinin bir meslek olarak algılanmasını sağlar & 2,07 & 967 \\
\hline $\begin{array}{l}\text { 24. Yasa çıktıktan sonra sadece çalışma kartı olan rehberler mesleği icra } \\
\text { etmektedir }\end{array}$ & 2,86 & 1,183 \\
\hline 25. Yeni yasada Türkiye turunun 45 güne çıkarılması yerinde bir uygulamadır & 2,53 & 1,156 \\
\hline 26. Meslek yasası mesleğimizde bir iyileștirmeye yol açmamıştır & 2,95 & 1,255 \\
\hline 27. Meslek odalarına kayıt zorunluluğu yerinde ve doğru bir uygulamadır & 2,39 & 1,146 \\
\hline 28. Yeni yasayı tam olarak anladığımı düşünüyorum & 2,68 & 1,148 \\
\hline 29. Taban ücret uygulaması meslek yasası ile yaygınlaşmıştır & 2,79 & 1,042 \\
\hline $\begin{array}{l}\text { 30. Bu anket meslek yasasının değerlendirilmesinde yeterli ve doğru ifadeleri } \\
\text { içermektedir }\end{array}$ & 2,40 & 1,190 \\
\hline
\end{tabular}

Tablo 3'te araştırmaya katılan turist rehberlerinin meslek yasasına yönelik tutumlarının ortalamaları incelenmiştir. Tabloya göre, en yüksek ortalamaya sahip ifade "4.Meslek yasası rehberlere devamlı iş garantisi sağlar" $(3,07)$ İfadesi iken en düşük ortalamaya ise "Meslek yasası rehberlik mesleğinin bir meslek olarak algılanmasını sağlar " $(2,07)$ İfadesidir. Katılımcıların ifadelere verdikleri cevapların ortalamalarına göre; meslek yasası ile sezonluk ya da süreli iş algısının bir nebze de olsa giderildiği; turist rehberlerinin yasa ile yıl boyunca çalışabilecekleri bir iş statüsüne kavuşabileceğine dair olumlu düşündükleri görülmektedir. Bununla birlikte; katılımcılar meslek yasasının getirilmesinde temel sebeplerden biri olan turist rehberliğinin mesleki bir statüye kavuşması amacının gerçekleşebileceğine inanmamaktadırlar.

Tablo 4'te meslek yasasına yönelik tutumların cinsiyet değişkenine göre farkııı̆ını tespit etmek için T-Testi yapılmıştır. Tablodan yola çıkarak meslek yasasına yönelik tutum ile cinsiyet değişkeni arasında istatistiksel açıdan anlamlı bir farklılık olduğu söylenebilmektedir. Yapılan Tukey testi sonucunda ise; Erkek katılımcıların 
kadın katılımcılara oranla meslek yasasına ilişkin tutumlarının daha düşük olduğu görülmektedir. Bu durumda H1 kabul edilmiştir.

Tablo 4: Meslek Yasasına Yönelik Görüşlerin Cinsiyet Değişkenine Göre T-Testi

\begin{tabular}{|l|c|c|c|c|}
\hline \multicolumn{1}{|c|}{ Cinsiyet } & $\mathbf{n}$ & $\bar{X}$ & $\mathbf{t}$ & $\mathbf{p}$ \\
\hline Kadın & 106 & 2,68 & \multirow{2}{*}{3,006} & \multirow{2}{*}{003} \\
\hline Erkek & 236 & 2,48 & \\
\hline
\end{tabular}

Tablo 5: Meslek Yasasına Yönelik Görüşlerin Eğitim Değişkenine Göre AnovaTesti

\begin{tabular}{|c|c|c|c|c|c|}
\hline Eğitim & $\mathbf{n}$ & $\bar{X}$ & $\mathbf{F}$ & p & Tukey \\
\hline Lise & 21 & 2,28 & \multirow{5}{*}{11,397} & \multirow{5}{*}{, 000} & \multirow{5}{*}{$\begin{array}{l}\text { *Lise-Önlisans } \\
\text { *Lise- Lisansüstü } \\
\text { *Önlisans- Lisans }\end{array}$} \\
\hline Ön lisans & 85 & 2,80 & & & \\
\hline Lisans & 211 & 2,45 & & & \\
\hline Lisansüstü & 28 & 2,69 & & & \\
\hline Toplam & 345 & 2,55 & & & \\
\hline
\end{tabular}

Tablo 5’te katılımcıların meslek yasasına ilişkin görüşlerinin eğitim değişkenine göre farklılığını tespit etmek için Anova testi yapılmıştır. Tabloya göre; meslek yasasına yönelik tutum ile eğitim değişkeni arasında istatistiksel açıdan anlamlı bir farklılık görülmektedir. Tukey testi sonuçlarına göre bu farklılığın Lise eğitim düzeyine sahip katılımcılar ile önlisans eğitim düzeyine sahip katılımcılar; Lise eğitim düzeyine sahip katılımcılar ile Lisansüstü eğitim düzeyine sahip katılımcılar; Önlisans eğitim düzeyine sahip katılımcılar ile Lisans eğitim düzeyine sahip katılımcılar arasında gerçekleştiği tespit edilmiştir. Lise mezunu olan katılımcıların önlisans ve Lisansüstü mezunu katılımcılara göre meslek yasasına yönelik tutumlarının daha düşük olduğu görülmektedir. Sonuçlara göre $\mathrm{H} 2$ kabul edilmiştir.

\section{Tablo 6: Meslek Yasasına Yönelik Görüşlerin Gelir Durumu Değişkenine Göre Anova-Testi}

\begin{tabular}{|c|c|c|c|c|c|}
\hline Aylık Gelir & $\mathbf{n}$ & $\bar{X}$ & $\mathbf{F}$ & $\mathbf{p}$ & Tukey \\
\hline Belirtilmemiş & 2 & 2,80 & \multirow{9}{*}{4,605} & \multirow{9}{*}{,000 } & \multirow{9}{*}{$\begin{array}{l}{ }^{*} 1001 / 2000 \text { TL- 2001-3000 TL } \\
{ }^{*} 1001 / 2000 \text { TL- 3001-4000 TL } \\
{ }^{*} 1001 / 2000 \text { TL- 4001-5000 TL } \\
{ }^{*} 1001 / 2000 \text { TL- 5001-6000 TL }\end{array}$} \\
\hline 1000 TL'den az & 35 & 2,71 & & & \\
\hline $1001-2000 \mathrm{TL}$ & 63 & 2,81 & & & \\
\hline $2001-3000 \mathrm{TL}$ & 97 & 2,54 & & & \\
\hline $3001-4000 \mathrm{TL}$ & 72 & 2,40 & & & \\
\hline $4001-5000 \mathrm{TL}$ & 44 & 2,36 & & & \\
\hline $5001-6000 \mathrm{TL}$ & 21 & 2,38 & & & \\
\hline 6000 TL'den fazla & 11 & 2,54 & & & \\
\hline Toplam & 345 & 2,55 & & & \\
\hline
\end{tabular}

Tablo 6'da katılımcıların meslek yasasına yönelik görüşlerinin gelir durumu değişkenine göre farklıığını tespit etmek için Anova testi yapılmıştır. Tabloya göre; meslek yasasına yönelik tutum ile gelir durumu arasında istatistiksel açıdan anlamlı bir farklılık görülmektedir. Tukey testi sonuçlarına göre, bu farkıığın; 1001-2000 TL ile 2001-3000 TL ; 3001-4000 TL ; 4001-5000 TL; 5001-6000 TL arasında olduğu 
görülmektedir. 1001/2000 TL gelir durumu olan katılımcıların 2001-3000 TL, 30014000 TL; 4001-5000 TL, 5001-6000 TL gelir durumu olan katılımcılara göre; meslek yasası ifadelerine daha yüksek bir oranla katıldığı görülmektedir. Bu durumda H3 kabul edilmiştir. Tablo 7: Meslek Yasasına Yönelik Görüşlerin Rehberlik Statüsü Değişkenine
Göre Anova-Testi

\begin{tabular}{|c|c|c|c|c|c|}
\hline $\begin{array}{l}\text { Rehberlik } \\
\text { Statüsü }\end{array}$ & $\mathbf{n}$ & $\bar{X}$ & $\mathbf{F}$ & p & Tukey \\
\hline Belirtilmemiş & 0 & 2,15 & \multirow{8}{*}{4,180} & \multirow{8}{*}{000} & \multirow{8}{*}{$\begin{array}{l}\text { *Belirtilmemiş- Eylemsiz Rehber } \\
\text { *Belirtilmemiş- Memur Rehber } \\
\text { *Belirtilmemiş- Öğrenci Rehber }\end{array}$} \\
\hline Eylemli Rehber & 43 & 2,47 & & & \\
\hline $\begin{array}{l}\text { Eylemsiz } \\
\text { Rehber }\end{array}$ & 4 & 2,71 & & & \\
\hline Memur Rehber & 8 & 2,63 & & & \\
\hline Öğrenci Rehber & 2 & 2,71 & & & \\
\hline Çalışmıyorum & 5 & 2,53 & & & \\
\hline Diğer & & 2,30 & & & \\
\hline Toplam & 45 & 2,55 & & & \\
\hline
\end{tabular}

Tablo 7'de katılımcıların meslek yasasına yönelik görüşlerinin rehberlik statüsü değişkenine göre farklılığını tespit etmek için Anova testi yapılmıştır. Tabloya göre; meslek yasasına yönelik tutum ile rehberlik statüsü değişkeni arasında istatistiksel açıdan anlamlı bir farklılık görülmektedir. Tukey testi sonuçlarına göre; Rehberlik durumunu belirtmemiş katılımcıların eylemsiz rehberlere, memur rehberlere, öğrenci rehberlere göre ifadelere daha düşük oranda katıldığı görülmektedir. Sonuçlara göre H4 kabul edilmiştir.

Tablo 8: Meslek Yasasına Yönelik Görüşlerin Mesleki Tecrübe Değişkenine Göre Anova-Testi

\begin{tabular}{|c|c|c|c|c|c|}
\hline Mesleki Tecrübe & $\mathbf{n}$ & $\bar{X}$ & $\mathbf{F}$ & $\mathbf{p}$ & Tukey \\
\hline 1 Yildan az & 9 & 2,50 & \multirow{6}{*}{3,860} & \multirow{6}{*}{, 004} & \multirow{6}{*}{$\begin{array}{l}\text { *1/3 YII- 4/6 YII } \\
\text { *1/3 YII-10 yıldan fazla }\end{array}$} \\
\hline 1-3 YII & 0 & 2,74 & & & \\
\hline 4-6 YII & 05 & 2,45 & & & \\
\hline 7-10 YII & 5 & 2,56 & & & \\
\hline 10 Yıldan fazla & 6 & 2,47 & & & \\
\hline Toplam & 45 & 2,55 & & & \\
\hline
\end{tabular}

Tablo 8'de katılımcıların meslek yasasına yönelik görüşlerinin mesleki tecrübe değişkenine göre farklılığını tespit etmek için Anova testi yapılmıştır. Tabloya göre; meslek yasasına yönelik tutum ile mesleki tecrübe değişkeni arasında istatistiksel 
açıdan anlamlı bir farklııı görülmektedir. Tukey testi sonuçlarına göre bu farklııı; 1-3 yıl ile 4-6 yıl ve 10 yıldan fazla rehberlik tecrübesine sahip rehberler arasında olduğu görülmektedir. 1-3 yıl rehberlik tecrübesi olan katılımcıların; 4-6 yıl arasında rehberlik tecrübesine sahip olan katılımcılar ile 10 yıldan daha fazla rehberlik tecrübesine sahip olan katılımcılara göre ifadelere daha yüksek bir oranda katılmaktadır. Bu durumda H5 kabul edilmiştir.

Tablo 9: Meslek Yasasına Yönelik Görüşlerin Ruhsatname Alma Yeri Değişkenine Göre Anova-Testi

\begin{tabular}{|c|c|c|c|c|c|}
\hline $\begin{array}{l}\text { Ruhsatname } \\
\text { Alma Yeri }\end{array}$ & $\mathbf{n}$ & $\bar{X}$ & $\mathbf{F}$ & $\mathbf{p}$ & Tukey \\
\hline Belirtilmemiş & & 2,64 & \multirow{6}{*}{4,870} & \multirow{6}{*}{,001 } & \multirow{6}{*}{$\begin{array}{l}\text { *Ön Lisans Diploması- Meslek } \\
\text { Kursları } \\
\text { * Ön Lisans Diploması- Lisans } \\
\text { Diploması }\end{array}$} \\
\hline Meslek Kursları & 1 & 4,43 & & & \\
\hline $\begin{array}{l}\text { Ön Lisans } \\
\text { Diploması }\end{array}$ & 0 & 2,76 & & & \\
\hline $\begin{array}{l}\text { Lisans } \\
\text { Diploması }\end{array}$ & 62 & 2,51 & & & \\
\hline Diğer & & 2,37 & & & \\
\hline Toplam & 45 & 2,55 & & & \\
\hline
\end{tabular}

Tablo 9'da katılımcıların meslek yasasına yönelik görüşlerinin ruhsatname alma yeri değişkenine göre farklılığını tespit etmek için Anova testi yapılmıştır. Tabloya göre; meslek yasasına yönelik tutum ile ruhsatname alma yeri değişkeni arasında istatistiksel açıdan anlamlı bir farklılık görülmektedir. Tukey testi sonuçlarına göre bu farklııı; önlisans diploması ile meslek kursları ve lisans diploması arasında görülmektedir. Önlisans diplomasına sahip katılımcıların; meslek kursları ve lisans diploması ile ruhsatname almış katılımcılara göre ifadelere daha yüksek bir oranda cevap verdiği görülmektedir. Verilere göre H6 kabul edilmiştir.

\section{Tablo 10: Meslek Yasasına Yönelik Görüşlerin Ekli Yabancı Dil Sayısı Değişkenine Göre Anova-Testi}

\begin{tabular}{|c|c|c|c|c|c|}
\hline Ekli Yabancı Dil Sayısı & & $\bar{X}$ & $\mathbf{F}$ & $\mathbf{p}$ & Tukey \\
\hline Tek Yabancı Dil & 03 & 2,62 & \multirow{5}{*}{3,374} & \multirow{5}{*}{, 019} & \multirow{5}{*}{$\begin{array}{l}\text { *Tek Yabancı Dil- } 2 \\
\text { Yabancı Dil }\end{array}$} \\
\hline 2 Yabancı Dil & 14 & 2,43 & & & \\
\hline 3 Yabancı Dil & 6 & 2,45 & & & \\
\hline 3 Yabancı Dil'den fazla & & 2,45 & & & \\
\hline Toplam & 45 & 2,55 & & & \\
\hline
\end{tabular}

Tablo 10'da katılımcıların meslek yasasına yönelik görüşlerinin ekli yabancı dil sayısı değişkenine göre farklılığını tespit etmek için Anova testi yapılmıştır. Tabloya göre; meslek yasasına yönelik tutum ile meslek yasası değişkeni arasında istatistiksel açıdan anlamlı bir farklılık görülmektedir. Tukey testi sonuçlarına göre bu farklılık; tek yabancı dil ile iki yabancı dil arasında görülmektedir. İki yabancı dile sahip katılımcıların tek yabancı dile sahip katılımcılara göre ifadelere yönelik ortalamalarının daha düşük bir oranda olduğu görülmektedir. Sonuçlara göre H7 kabul edilmiştir. 


\section{Sonuç ve Öneriler}

Bu çalışmada 6326 Sayılı Turist Rehberliği Meslek Kanunu'na yönelik turist rehberlerinin tutumlarını ve görüşlerini ortaya çıkarmak amaçlanmaktadır. Yasa'nın çıkış tarihi oldukça yeni olmakla birlikte; yasanın çıkması ile turist rehberliği mesleğine dair pek çok konuda iyileştirmenin gerçekleşeceği önceki çalışmalarda da dile getirilmektedir. "6326 Sayılı Turist Rehberliği Meslek Kanunu" yıllardır rehberlerin bekledikleri bir yasadır. Bu kanun ile birlikte rehberlik mesleğinin bir statüye kavuşması; yasal hakların kazanılması, işletme ve yöneticilerle ilişkilerin düzenlenmesi, kaçak rehberlik ve taban ücret sorunlarının çözümlenmesi beklenmiştir. Literatür incelendiğinde turist rehberlerine yönelik farklı alanlarda araştırmaların yer aldığı görülmektedir (Akbulut, 2006; Ap ve Kevin, 2001; Batman, 2000; Bowie ve Chi, 2005; Çetin, 2012; Güzel, 2007; Köroğlu, 2013; Köroğlu ve Avcıkurt, 2014; Lecrec ve Martin, 2004; Temizkan vd., 2014; Tetik, 2006; Tosun ve Temizkan, 2004; Wang ve Cheng, 2000; Yarcan, 2007; Yenipınar ve Çapar, 2014; Zhang, 2004). Ancak mevcut literatür incelendiğinde ise; Meslek yasasına yönelik tutumları ve bu tutumların demografik özelliklere göre değişimini ölçen bir çalışmaya rastlanılmamıştır. Bu sebeple çalışmanın literatüre katkı sağlayacağı düşünülmektedir.

Görünen odur ki yasada yapılan pek çok değişiklik rehberler tarafından olumlu karşılanmış ve doğru birer uygulama olarak görülmüştür. Ancak yasanın uygulanması ve yaptırımların denetlenmesi konusundaki eksiklikler rehberleri yasal haklarının korunmadığı düşüncesine itmiştir. Dolayısıyla kanunun mevcut hali ile beklentileri tam olarak karşılamadığını söylemek mümkündür (Yenipınar, Bak ve Çapar: 2014).

Konuyla ilgili olarak yasanın yeniden revize edilmesi ve eksikliklerin giderilmesi önerilebilir. Özellikle sertifika programlarının yetersizliği konusunda getirilen eleştiriler dikkate alındığında (Temizkan, Temizkan ve Tokay, 2013) rehberlik eğitimi konusunda mevcut yeni yasada da eksiklikler olduğunu söylemek mümkündür. Bu bağlamda bundan sonra yasada yapılacak düzenlemelerle ilgili olarak akademik camia ve meslek kuruluşlarının da görüşlerinin alınması önem arz etmektedir.

Rehberlerin meslek yasasına ilişkin görüşleri incelendiğinde; meslek yasasının devamlı bir iş garantisi sağlayacağı, rehberler ile acentalar arasında yasal bir zemin hazırlayacağı konusunda yüksek bir oranda olumlu görüşlerini ifade etmişlerdir. Uzun yıllardan beri devam eden rehberlik mesleği gelişim süreci meslek kanunu ile hız kazanmıştır. Bilindiği üzere turist rehberlerinin sorunları arasında; rehberlik mesleğinin iş garantisinin olmaması ve acentalar ile yaşanan mevzuata yönelik anlaşmazlıklar gelmektedir. Meslek yasası ile rehberlerin verimliliğini ve motivasyonunu olumlu düzeyde etkileyecek, işten ayrılma niyetlerinde gözle görülür şekilde bir düşüş yaşanacaktır. Turist rehberleri meslek yasası ile turist rehberlerinin mesleklerinde bir iyileştirme olacağı ve olumlu bir seyir izleyeceği görüşüne varmışlardır.

Katılımcıların cinsiyetleri, eğitim durumları, gelir düzeyleri, rehberlik statüsü, mesleki tecrübe, ruhsatname alma yeri, bildikleri yabancı diller, mesleki tecrübe ile meslek kanuna ilişkin tutumları arasında anlamlı bir farklılık tespit edilmiştir. Kadın katılımcıların erkeklere göre; Lise eğitim düzeyinin ön lisans ve lisans eğitim düzeyine göre; 1001/2000 TL gelir düzeyine sahip katılımcıların 2001-3000 TL, 3001-4000 TL, 4001-5000 TL, 5001-6000 TL gelir düzeyine sahip katılımcılara göre; 1-3 yıl mesleki tecrübeye sahip katılımcıların 4-6 yıl ve 10 yıldan fazla mesleki tecrübeye sahip katılımcılara göre ifadelere daha büyük bir oranda katılım gösterdiği, "6326 Sayılı Turist Rehberliği Meslek Kanunu" na yönelik görüşlerinin daha yüksek olduğu tespit edilmiştir. 
Rehberlerin en fazla mağdur olduğu iki konu taban ücret ve kaçak rehberlik sorunudur. Bu hususta işletmelere sözleşmeler konusunda titiz davranmaları ve kanun hükümlerine uymaları önerilmektedir. Yine bu sorunların önlenebilmesi için bizzat meslek mensuplarının da titiz davranmaları ve mevzuatta belirtilen ücret düzeylerinin altında çalışmamaları gerekmektedir. Taban ücret sorununu doğuran en önemli sebep asında bizzat bir kısım rehberlerin kendileri ve ne yazık ki sertifikasız çalışan kişilerden kaynaklanmaktadır. Sonuçlardan hareketle kamuya, özel sektöre ve yeni araştırmacılara bazı önerilerde bulunulmuştur. Bu öneriler aşağıdaki gibidir;

Meslek kanununun belirli aralıklarla gözden geçirilerek; revize edilebilir.

6326 sayılı Turist Rehberliği Meslek Kanununu tüm rehberlere ulaştırmak, ve yanlış anlaşılmalara yol açmamak adına net ve daha anlaşılır ifadelerin olması

Meslek Kanununa yönelik eleştiri ve tavsiyeler dikkate alınmalı, turizm sektörünün konjonktürel yapısı göz önünde bulundurulmalıdır.

Turist Rehberliğinin kademeli eğitimi göz önünde bulundurulmalı, ön lisans lisans eğitimi ya da rehberlik kursları arasında bir ayrım bulunmalıdır.

Taban ücretlerinin altında ücret almamak adına kontroller arttırılmalı, seyahat acentalarının turist rehberleri ile yaptıkları sözleşme ya da ücretlendirme hususunda daha ciddi bir yaklaşım benimsenmelidir.

Rehberlerin paydaşlar ya da müşteri ile yaşadıkları sıkıntılarda, karşılaştıkları farklı sorunlarda danışabileceği birimlerin turist rehberini daha koruyucu bir yaklaşım içinde olması gerekmektedir.

Turist Rehberliğinde eğitimin önemi bilinmektedir. Sertifika programlarında da benzer bir bakış açısı benimsenmeli ve üniversitelerin fikir ve atılımları benimsenmelidir.

Araştırmadan elde edilen veriler; turist rehberlerinin cinsiyetleri, eğitim durumları, gelir düzeyleri, rehberlik statüsü, mesleki tecrübe, ruhsatname alma yeri, bildikleri yabancı diller, mesleki tecrübe ile meslek kanuna göre farklılaşıp farklılaşmadığını ölçmeyi amaçlamıştır. Ancak elde edilen sonuçların sadece belirli bir dönemi ve o dönemin koşullarını kapsadığını ifade etmek mümkündür. Konuya ilgi duyan araştırmacılar; benzer ölçek ve değişkenleri farklı zamanlarda uygulaması önerilebilir. Ayrıca tek bir değişkenin bile meslek yasasına yönelik karar ve yargılarda ne kadar önemli olduğunu düşünürsek; bir değişken için de meslek yasasına yönelik tutumlar ölçülebilir. Ayrıca yasaya direk ya da dolaylı olarak etkisi olan tüm paydaşlar ile görüşülmesi ve mevcut durumun ortaya konulması da yeni araştırmacılar için bir diğer öneri niteliğindedir.

\section{Kaynakça}

Ahipaşaoğlu, S. (2001). Turizmde Rehberlik. Ankara: Detay Yayıncılık.

Akbulut, O. (2006). Ege Bölgesindeki Profesyonel Turist Rehberlerinin Mesleki Sorunları ve Çözüm Önerilerine Yönelik Bir Araştırma . Yüksek Lisans Tezi, Akdeniz Üniversitesi, Antalya.

Ap, J., ve Wong, K. K. (2001). Case Study on Tour Guiding: Professionalism, Issues and Problems. Tourism Management, 22, 551-563.

Avcıkurt, C., Alper, B., \& Geyik, S. (2009). Education and trainig of Turist Guide in Turkey. Management and Education, 1, 57-63.

Batman, O. (2003). Türkiye'deki Profesyonel Turist Rehberlerinin Mesleki Sorunlarına Yönelik Bir Araştırma. Bilgi Dergi, 2, 117-134.

Batman, O., Yıldırgan, R., ve Demirtaş, N. (2000). Turizm Rehberliği. Sakarya: Değişim Yayınları. 
Bowie, D., ve Chang, J. C. (2005). Tourist Satisfaction: A View from a Mixed International Guided Package Tour. . 11 (4). ss. 303-322. Journal of Vocational Marketing, 11(4), 303-322.

Cohen, E. (1985). The Tourist Guide: The Origins, Structure And Dynamics of a Role. Annals Of Tourism Research, 12(1), 378-398.

Çetin, G., ve Kılırmak, İ. (2012). Türk Turizminde Kokartlı Turist Rehberlerinin Mevcut Durumunun Analizi. Afyon Kocatepe Üniversitesi IIBF Dergisi, 14(2), 307-318.

Çimrin, H. (1995). Turizm ve Turist Rehberliğinin ABC'si. Antalya: Akdeniz Kitabevi.

Dahles, H. (2002). The Politics of Tour Guiding; Image Management in Indonesia. Annals of Tourism Research, 29(3), 783-800.

Güzel, Ö. F. (2007). Türkiye İmajının Geliştirilmesinde Profesyonel Turist Rehberlerinin Rolü, Balıkesir Üniversitesi, Sosyal Bilimler Enstitüsü Yükseklisans Tezi,.

Güzel, Ö., Türker, A., ve Şahin, İ. (2014). Profesyonel Turist Rehberlerinin Algıladıkları Mesleki Engelleri Belirlemeye Yönelik Bir Araştırma. Gazi Üniversitesi Turizm Fakültesi Dergisi, 2, 173-190.

Köroğlu, Ö. (2013). Turist rehberlerinin İş Yaşamındaki Rolleri Üzerine Kavramsal Bir Değerlendirme. Pamukkale Üniversitesi Sosyal Bilimler Enstitüsü Dergisi(16), 91-112.

Köroğlu, Ö.,ve Avcıkurt, C. (2014). Turist Rehberlerin Motivasyonu ile Performansı Arasındaki İlşkinin Belirlenmesi. Dumlupınar Üniversitesi Sosyal Bilimler Dergisi(39), 45-60.

Lecrec, D., ve Martin, J. N. (2004). Tour guide Communication Competence: French, Germanand Americantourists' Perceptions. International Journal of Intercultural Relations, 28, 181-200.

Liu, D., ve Yee, A. (2012). Problem sand counter measures of Tour Guide Services in Liaoning Province. Canadian Social Science, 8(3), 94-97.

Ong, C.-E., \& Chris Ryan, A. M. (2014). Power-knowledge and Tour-Guide Training: Capitalistic Domination, Utopian Visions and the Creation and Negotiation of UNESCO's Homo Turismos in Macao. Annals of Tourism Research, 48, 221234.

Temizkan, P. S., Temizkan, R., \& Tokay, S. (2013). Turist Rehberliği Meslek Kanunu ve Turist Rehberi Eğitiminde Yeni Bir Paradoks. 14. Ulusal Turizm Kongresi, (s. 474-486). Kayseri.

Tetik, N. (2006). Türkiye'de Profesyonel Turist Rehberliği ve Müşterilerin Turist Rehberlerinden Beklentilerinin Analizi (Kuşadası Örneği). Yüksek lisans Tezi, Balıkesir Üniversitesi.

Tosun, C., ve Temizkan, R. (2004). Türkiye'nin Dış Tanıtım ve Ülke İmajında Turist Rehberlerinin Rolü. I. Balıkesir Ulusal Turizm Kongresi, (s. 345-365). Balıkesir.

Wang, K.-C., Hsieh, A.-T., ve Huan, T.-C. (2000). Critical Service Features in Group Package Tour: An Exploratory Research. Tourism Management, 177-189.

Yarcan, Ş. (2007). Profesyonel Turist Rehberliğinde Mesleki Etik Üzerine Kavramsal Bir Değerlendirme. Anatolia: Turizm Araştırmaları Dergisi, 18(1), 33-44.

Yenipınar, U., Bak, E., ve Çapar, G. (2014). Turist Rehberliği Meslek Kanununun, Meslek Örgütleri ve Öğretim Elemanlarının Bakış Açısı ile Değerlendirilmesi. Çağ Üniversitesi Sosyal Bilimler Dergisi, 11(2), 86-114.

Zhang, H. Q., ve Chow, I. (2004). Application of Importance-Performance Model in Tour Guides' Performance: Evidence From Mainland Chinese Outbound Visitors in Hong Kong. Tourism Management, 25(1), 81-91. 